\title{
Heavy Metals Tolerance in an Invasive Weed (Fallopia japonica) under Different Levels of Soils Contamination
}

\author{
Justyna Sołtysiak' \\ 1 Department of Botany and Plant Ecology, Wrocław University of Environmental and Life Sciences, Wrocław, \\ Poland \\ e-mail: justyna.soltysiak@upwr.edu.pl
}

\begin{abstract}
In order to assess the tolerance of the highly invasive weed Fallopia japonica to heavy metals, a greenhouse experiment was conducted in which this plant was cultivated in control soil and in the soils polluted by different levels of $\mathrm{Cd}, \mathrm{Cr}, \mathrm{Cu}, \mathrm{Pb}$ and $\mathrm{Zn}$. The content of heavy metals in soil did not eliminate the $F$. japonica rhizome's capacity to regenerate. However, at the beginning of the experiment, the presence of some metal doses: $\mathrm{Cd}\left(100,200 \mathrm{mg} \cdot \mathrm{kg}^{-1}\right)$, $\mathrm{Pb}\left(200 \mathrm{mg} \cdot \mathrm{kg}^{-1}\right)$ and $\mathrm{Zn}\left(300 \mathrm{mg} \cdot \mathrm{kg}^{-1}\right)$ delayed the rhizome regeneration compared to the control plants. In the soils contaminated with any level of $\mathrm{Cr}$ or $\mathrm{Pb}$, shoots grew with similar vigour to the control plants. Only the high doses of $\mathrm{Cd}\left(100,200 \mathrm{mg} \cdot \mathrm{kg}^{-1}\right), \mathrm{Cu}\left(300 \mathrm{mg} \cdot \mathrm{kg}^{-1}\right)$ and $\mathrm{Zn}\left(300 \mathrm{mg} \cdot \mathrm{kg}^{-1}\right)$ significantly delayed the plants' growth. The morphological features of $F$. japonica from the soils polluted with $\mathrm{Cr}$ and $\mathrm{Pb}$ were not significantly different from the control plants. Among the tested heavy metals that had the greatest impact on the morphology of $F$. japonica were $\mathrm{Cd}\left(100,200 \mathrm{mg} \cdot \mathrm{kg}^{-1}\right), \mathrm{Cu}\left(300 \mathrm{mg} \cdot \mathrm{kg}^{-1}\right)$ and $\mathrm{Zn}\left(300 \mathrm{mg} \cdot \mathrm{kg}^{-1}\right)$. A chemical analysis indicated that this weed accumulated large quantities of metals when cultivated in the contaminated soil. Particular attention was paid to its relatively high Cd uptake. In the variant where a dose of $100 \mathrm{mg} \mathrm{Cd} \cdot \mathrm{kg}^{-1}$ was applied, the plants (aboveground part) accumulated more than 630 times the amount of cadmium found in the control. The abilities of $F$. japonica to regenerate from rhizome fragments, to grow and develop under the stress conditions created by heavy metals, and to take up metals are evidence that this plant is characterised by metal tolerance.
\end{abstract}

Keywords: Polygonum cuspidatum, Japanese knotweed, biological invasions, heavy metal accumulation

\section{INTRODUCTION}

Biological invasions represent one of the main problems of contemporary ecology and are considered a significant component of the global change connected with human activity (Vilá et al. 2007). On the basis of the knowledge about the invasive plant species accrued from many studies, it can be concluded that the phenomenon of their invasiveness is determined by several characteristics that give the invader an advantage. These characteristics can be summarised as vigorous and rapid growth, high fecundity (Bradley et al. 2010), strong competing abilities (Sharma et al. 2005) and sexual reproduction by hybridisation, which may serve as a stimulus for the evolution of invasiveness (Ellstrand and Schierenbeck 2000). It has also been noted that in order to become a successful invader, a plant must possess wide environmental tolerances and be well-suited to various conditions (Bradley et al. 2010). A typical example of a plant that possesses such characteristics is the invasive weed Fallopia japonica from the Fallopia genus (Polygonaceae). It is native to East Asia, with a natural range that mainly encompasses China, Japan, North and South Korea, and Taiwan (Bailey 2003, CABI 2020). Fallopia japonica was deliberately introduced to Europe in the $19^{\text {th }}$ century as an ornamental plant. Today, $F$. japonica is viewed as Europe's worst invasive alien plant species (Nentwig et al. 2018) because it is spreading in almost all European countries. Globally, it is also now common in North America Australia, and New Zealand (Anderson and Hayley 2012). Apart from the natural areas, $F$. japonica occurs frequently in the man-made 
habitats such as roads, highways and railways (Tokarska-Guzik et al. 2017). The species is often observed in the places with extremely high levels of anthropogenic pollution; for instance, it can inhabit heavy-metal-polluted soils. In Poland, F. japonica was noted on a zinc smelter (Chmura et al. 2013), coal mining spoil heaps (Rahmonov et al. 2014) and urban parks with different levels of disturbance (Rahmonov et al. 2019). Preliminary field studies in the city of Wrockaw, Poland proved that an increased content of heavy metals in soil does not deter $F$. japonica invasion-on the contrary, it can even enhance the invader's competitiveness in relation to other plant species (Soltysiak et al. 2014). Taking into account the field observations in the literature, it was hypothesised that $F$. japonica has some tolerance to toxic metals. For this reason, a greenhouse experiment was conducted and the reaction of F. japonica to the stress conditions created by the presence of different levels of heavy metals in the soil was investigated. The aim of this research was to determine:

1) The ability of the highly invasive weed $F$. japonica to regenerate from rhizome segments in the soils polluted by various doses of $\mathrm{Cd}, \mathrm{Cr}$, $\mathrm{Cu}, \mathrm{Pb}$, and $\mathrm{Zn}$;

2) The toxic effects of these metals on the growth and development of the tested plant;

3) The possibility of $F$. japonica to accumulate heavy metals in its tissues.

$\mathrm{Cd}, \mathrm{Cr}, \mathrm{Cu}, \mathrm{Pb}$, and $\mathrm{Zn}$ were chosen as the stressors because they are widespread pollutants of soils in Central Europe, where the Fallopia japonica scrubs were noted (Soltysiak et al. 2011, Sołtysiak and Brej 2014, Rahmonov et al. 2014, Rahmonov et al. 2019).

\section{MATERIAL AND METHODS}

\section{Plant material}

Fallopia japonica (Houtt.) Ronse Decraene var. japonica [syn.: Polygonum cuspidatum Sieb. Et Zucc., Reynoutria japonica Houtt. var. japonica] belongs to the Fallopia genus (Polygonaceae), the members of which are known as successful invaders and are widespread across Europe, for instance, in Great Britain (Bailey 2003), Czech Republic (Mandák et al. 2005), Poland (Tokarska-Guzik et al. 2012), Slovakia (Pauková 2019),
Croatia (Vuković et al. 2019) as well as in North America, Australia and New Zealand (Bailey et al. 2008). Fallopia japonica is characterised by a facility for regenerating through subterranean rhizomes (underground stems) (Fennell et al. 2018). The extent of generative propagation in Europe is not known because of a lack of male clones of this species. The European F. japonica plants are represented by a genetically uniform clone with 88 chromosomes and male-sterile flowers (Mandàk et al. 2005, Bailey et al. 2008). The Fallopia japonica studied in the greenhouse experiment reported here was collected from the city of Wrocław (SW Poland). It was a female clone with 88 chromosomes. The species identification was based on the morphological features of the leaves (shape, size, hairiness of leaf blade) and a cytological examination in order to determine the number of chromosomes. Fresh rhizomes were collected from one cluster of a natural population of Fallopia japonica that grows along a bank of the Oder River $\left(51^{\circ} 07.404^{\prime} \mathrm{N}\right.$ and $\left.17^{\circ} 04.146^{\prime} \mathrm{E}\right)$. In the laboratory, the rhizomes of $F$. japonica were cleaned with distilled water and cut into fragments of a similar weight (12.5 g).

\section{Greenhouse experiment procedure}

The greenhouse experiment procedure was conducted according to a study by Sołtysiak and Brej (2019), where the effect of different doses of $\mathrm{Pb}$ on invasive Fallopia $\mathrm{x}$ bohemica (a hybrid of $F$. japonica and $F$. sachalinensis) was examined. The prepared plant materials (rhizome fragments of $F$. japonica) were introduced into plastic pots (one rhizome in each pot) with a capacity of $5 \mathrm{~kg}$ of soil. The soil with $\mathrm{pH}$ of 5.3 (determined in $\mathrm{KCl}$ ) and $1.2 \%$ organic matter was used in the experiments. The macronutrient contents were as follows: $\mathrm{K}_{2} \mathrm{O}-26.7 \mathrm{mg} \cdot 100 \mathrm{~g}^{-1}, \mathrm{P}_{2} \mathrm{O}_{5}-$ $11.6 \mathrm{mg} \cdot 100 \mathrm{~g}^{-1}$ and $\mathrm{Mg}-4.0 \mathrm{mg} \cdot 100 \mathrm{~g}^{-1}$, while the baseline heavy metal concentrations were $\mathrm{Cd}$ $-0.1 \mathrm{mg} \cdot \mathrm{kg}^{-1}, \mathrm{Cr}-6.7 \mathrm{mg} \cdot \mathrm{kg}^{-1}, \mathrm{Cu}-8.4 \mathrm{mg} \cdot \mathrm{kg}^{-1}$, $\mathrm{Pb}-10.2 \mathrm{mg} \cdot \mathrm{kg}^{-1}$ and $\mathrm{Zn}-27.1 \mathrm{mg} \cdot \mathrm{kg}^{-1}$. The experiment was a completely randomized twofactorial design with five heavy metals $(\mathrm{Cd}, \mathrm{Cr}$, $\mathrm{Cu}, \mathrm{Pb}$ and $\mathrm{Zn}$ ) and three different levels of each metal: $\mathrm{Cd}-20,100,200 \mathrm{mg} \cdot \mathrm{kg}^{-1}, \mathrm{Cr}-10,20$, $100 \mathrm{mg} \cdot \mathrm{kg}^{-1}, \mathrm{Cu}-100,200,300 \mathrm{mg} \cdot \mathrm{kg}^{-1}, \mathrm{~Pb}-50$, $100,200 \mathrm{mg} \cdot \mathrm{kg}^{-1}$ and $\mathrm{Zn}-100,200,300 \mathrm{mg} \cdot \mathrm{kg}^{-1}$. The individual metal solutions were applied directly into the pots. The pots with no addition of a heavy metal were treated as controls. Four 
replicates were created for each metal treatment and the control group. The greenhouse experiment was conducted during one growing season, from early June to September. The plants were grown under natural light and temperature conditions (varied from 20 to $30^{\circ} \mathrm{C}$ ) and watered every day.

\section{Plant observations, measurements, and heavy metal concentration analysis}

During the experiment, the regeneration, growth and development of $F$. japonica were observed every day. At the beginning, the ability of $F$. japonica rhizomes to regenerate in the soils polluted by various doses of $\mathrm{Cd}, \mathrm{Cr}, \mathrm{Cu}, \mathrm{Pb}$ and $\mathrm{Zn}$ was monitored for 3 weeks. Next, after the rhizome regeneration, the dynamic of $F$. japonica growth was noted. The height of the highest areal shoots of plants for each treatment group was measured on a centimetre scale once a week for 14 weeks. Afterwards, the morphological traits of plants, such as the length and width of the leaf blade $(\mathrm{cm})$, fresh and dry weights of aboveground shoots (g), were measured in a laboratory. Additionally, the concentrations of heavy metals in the aboveground organs (leaves) and underground organs (rhizomes) of F. japonica were analysed. For this purpose, the plant material was washed with distilled water. Next, it was dried at $80^{\circ} \mathrm{C}$ for $48 \mathrm{~h}$, milled with a stainless-steel grinder and digested in a mixture of $\mathrm{HCl}$ and $\mathrm{HNO}_{3}$ (at a ratio of 3:1). The contents of metals in the leaves and rhizomes were analysed (each sample in four replications) with the ICP-OES (Inductively Coupled Plasma Optical Emission Spectroscopy) technique using a Varian Liberty Series 220 spectrometer. The analyses were performed in a laboratory of the Centre of Analysis of Environmental Quality at the Wrocław University of Life Sciences.

\section{Statistical analyses}

The statistical analyses were carried out using STATISTICA v. 13.3 (StatSoft Inc., 2017). The normality of the data distribution was checked using the Shapiro-Wilk test. The homogeneity of variance was checked using Levene's test. The morphological characteristics of the plants grown under different conditions (i.e., in the pots with soil contaminated by various doses of $\mathrm{Cd}, \mathrm{Cr}, \mathrm{Cu}$, $\mathrm{Zn}$, or $\mathrm{Pb}$ or in the control soils) were compared using one-way ANOVA. Homogeneous subsets were designated using the post-hoc testing of significance of differences with Tukey's HSD test. In order to determine the relationship between various heavy metal doses and their contents in the aboveground and underground parts of the plants, the correlation coefficients were determined: Pearson's correlation coefficient (p) in the case of the data for which a normal distribution was found and Spearman's rank correlation coefficient (Rs) for the data with a non-normal distribution.

\section{RESULTS}

\section{The influence of heavy metals on regeneration ability and growth of Fallopia japonica}

The results confirmed the ability of Fallopia japonica rhizomes to regenerate in the soils polluted by heavy metals (Table 1). However, at the beginning of the experiment, the presence of $\mathrm{Cd}$ $\left(100,200 \mathrm{mg} \cdot \mathrm{kg}^{-1}\right), \mathrm{Pb}\left(200 \mathrm{mg} \cdot \mathrm{kg}^{-1}\right)$ and $(\mathrm{Zn}$ $\left(300 \mathrm{mg} \cdot \mathrm{kg}^{-1}\right)$ delayed rhizome regeneration compared to the control plants. After the three weeks of cultivation, the highest regeneration $(100 \%)$ rates were exhibited by the plants from the control pots and the pots polluted by $\mathrm{Cd}(20,100$, $\left.200 \mathrm{mg} \cdot \mathrm{kg}^{-1}\right), \mathrm{Cr}\left(10,20,100 \mathrm{mg} \cdot \mathrm{kg}^{-1}\right), \mathrm{Cu}(100$, $\left.200 \mathrm{mg} \cdot \mathrm{kg}^{-1}\right)$ and $\mathrm{Zn}\left(100,200 \mathrm{mg} \cdot \mathrm{kg}^{-1}\right)$. The fewest rhizomes $(75 \%)$ showed active regeneration in the pots with addition of $\mathrm{Cu}$ and $\mathrm{Zn}$ in a doses of $300 \mathrm{mg} \cdot \mathrm{kg}^{-1}$ and all $\mathrm{Pb}$ doses $(50,100$, $\left.200 \mathrm{mg} \cdot \mathrm{kg}^{-1}\right)$.

The study showed that $\mathrm{Cr}\left(10,20,100 \mathrm{mg} \cdot \mathrm{kg}^{-1}\right)$ and $\mathrm{Pb}\left(50,100,200 \mathrm{mg} \cdot \mathrm{kg}^{-1}\right)$ did not inhibit the growth of the aerial shoots of Fallopia japonica. The plant heights obtained in soils where $\mathrm{Cr}$ or $\mathrm{Pb}$

Table 1. Regeneration of $F$. japonica rhizomes (\%) in individual variants of the experiment

\begin{tabular}{|c|c|c|c|c|c|c|c|c|c|c|c|c|c|c|c|c|c|}
\hline \multicolumn{3}{|c|}{ Metals } & \multicolumn{3}{|c|}{$\mathrm{Cd}$} & \multicolumn{3}{|c|}{$\mathrm{Cr}$} & \multicolumn{3}{|c|}{$\mathrm{Cu}$} & \multicolumn{3}{|c|}{$\mathrm{Pb}$} & \multicolumn{3}{|c|}{$\mathrm{Zn}$} \\
\hline \multicolumn{2}{|l|}{$\begin{array}{c}\text { Doses } \\
{\left[\mathrm{mg} \mathrm{kg}^{-1}\right]}\end{array}$} & Control & 20 & 100 & 200 & 10 & 20 & 100 & 100 & 200 & 300 & 50 & 100 & 200 & 100 & 200 & 300 \\
\hline \multirow{3}{*}{$\begin{array}{l}\text { Time after } \\
\text { plantation } \\
\text { [weeks] }\end{array}$} & 1 & 50 & 25 & 0 & 0 & 50 & 50 & 50 & 50 & 25 & 25 & 50 & 25 & 0 & 25 & 50 & 0 \\
\hline & II & 100 & 50 & 50 & 50 & 100 & 100 & 100 & 100 & 50 & 75 & 50 & 50 & 50 & 75 & 100 & 75 \\
\hline & III & 100 & 100 & 100 & 100 & 100 & 100 & 100 & 100 & 100 & 75 & 75 & 75 & 75 & 100 & 100 & 75 \\
\hline
\end{tabular}


was added corresponded with those of the control plants. The metals such as $\mathrm{Cd}, \mathrm{Cu}$, or $\mathrm{Zn}$ had an inhibitory effect on the plant growth. After 14 weeks of observations, the final height of $F$. japonica growing in the pots with $\mathrm{Cd}(20,100$ and $\left.200 \mathrm{mg} \cdot \mathrm{kg}^{-1}\right), \mathrm{Cu}\left(100,200\right.$ and $\left.300 \mathrm{mg} \cdot \mathrm{kg}^{-1}\right)$ and $\mathrm{Zn}\left(100,200,300 \mathrm{mg} \cdot \mathrm{kg}^{-1}\right)$ was lesser than that of the control plants. The addition of $\mathrm{Cd}$ at a dose of $200 \mathrm{mg} \cdot \mathrm{kg}^{-1}$ resulted in the plant growth arrest in the eighth week of the experiment (Figure 1a).

\section{The influence of heavy metals on morphological features of $F$. japonica}

Figure 2 (a-d) presents the observed morphological features of Fallopia japonica in the soil

a)

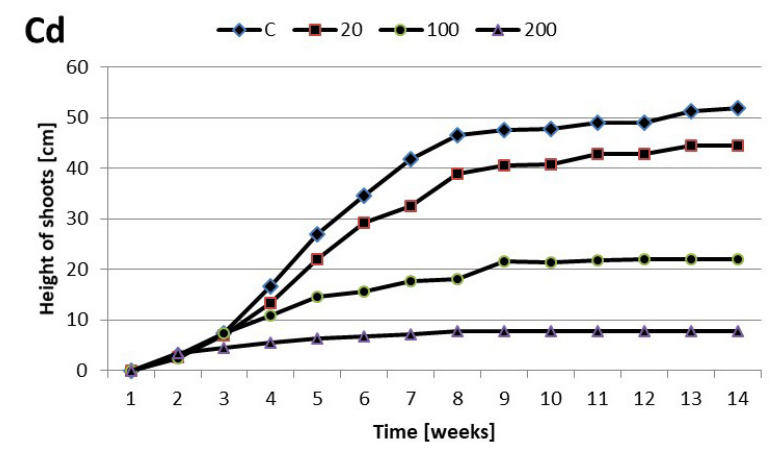

c)

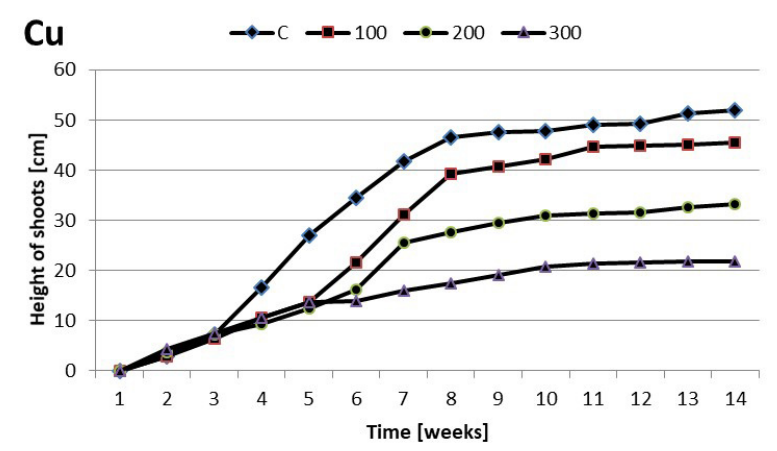

cultures with the addition of various metals and in the control variant. Among the tested heavy metals that had the greatest impact on the morphology of $F$. japonica were $\mathrm{Cd}\left(100\right.$ and $\left.200 \mathrm{mg} \cdot \mathrm{kg}^{-1}\right)$, $\mathrm{Cu}\left(300 \mathrm{mg} \cdot \mathrm{kg}^{-1}\right)$ and $\mathrm{Zn}\left(300 \mathrm{mg} \cdot \mathrm{kg}^{-1}\right)$. The plants from the soils that were polluted by the highest dose of $\mathrm{Cd}\left(200 \mathrm{mg} \cdot \mathrm{kg}^{-1}\right)$ differed significantly from those in the control pots. The length and width of the leaf blade were significantly smaller $(\mathrm{F}=36.5572, \mathrm{P}=0.00003$ and $\mathrm{F}=12.4793$, $\mathrm{P}=0.000534$, respectively). The fresh weight of the aboveground shoots was almost twenty times lower compared to control $(\mathrm{F}=30.4288$, $\mathrm{P}<0.0001$ ), while the dry weight of aboveground shoots was forty times lower $(\mathrm{F}=53.1501$, $\mathrm{P}<0.0001)$. The smallest dose of $\mathrm{Cd}$ did not have

b)

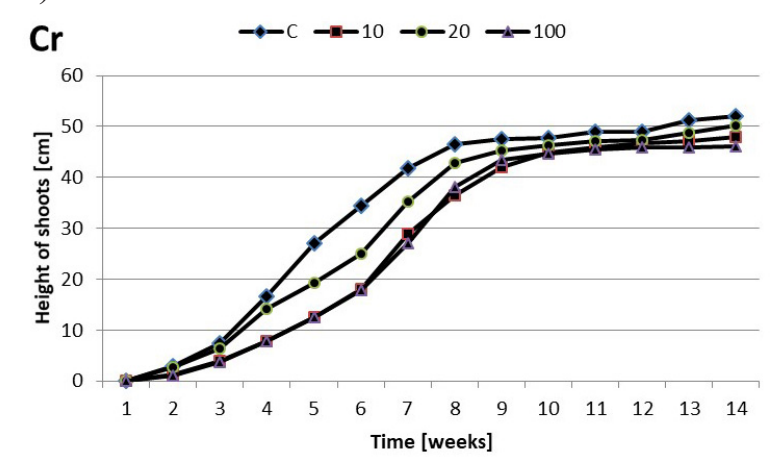

d)

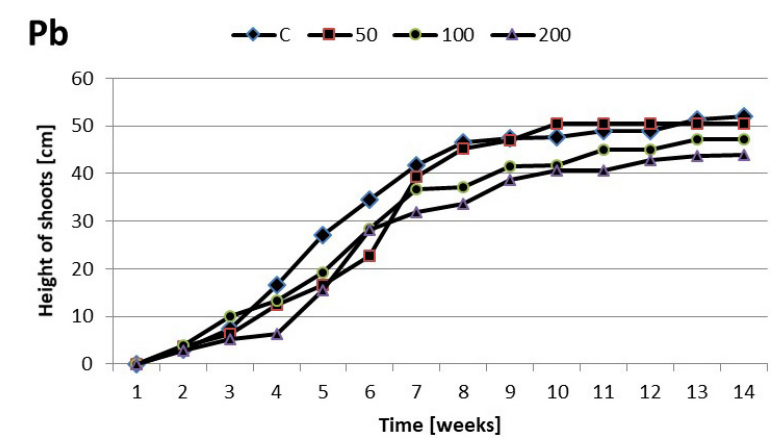

e)

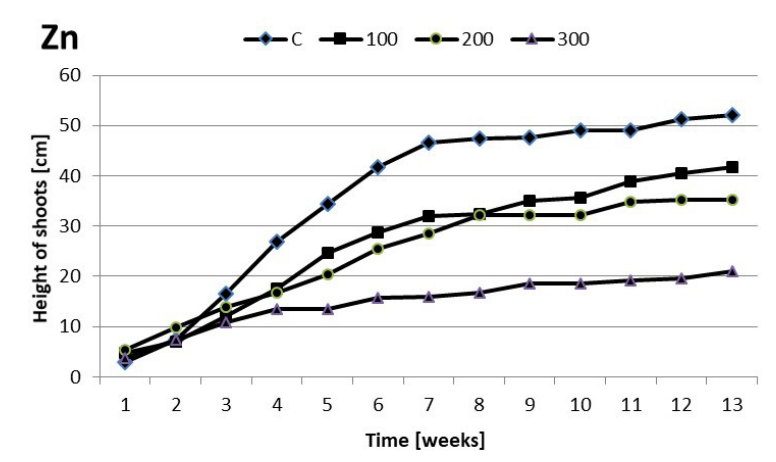

Figure 1. Growth of aboveground shoots of Fallopia japonica in control variant - C. and in soil cultures with the addition of various metal doses: a) $\mathrm{Cd}-20,100,200 \mathrm{mg} \cdot \mathrm{kg}^{-1}$; b) $\mathrm{Cr}-10,20,100 \mathrm{mg} \cdot \mathrm{kg}^{-1}$;

c) $\mathrm{Cu}-100,200,300 \mathrm{mg} \cdot \mathrm{kg}^{-1}$; d) $\mathrm{Pb}-50,100,200 \mathrm{mg} \cdot \mathrm{kg}^{-1}$; e) $\mathrm{Zn}-100,200,300 \mathrm{mg} \cdot \mathrm{kg}^{-1}$ 
a)

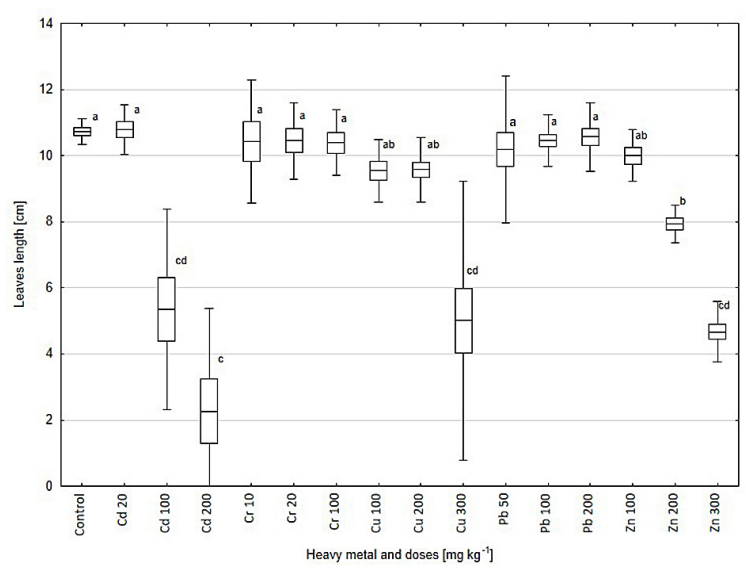

c)

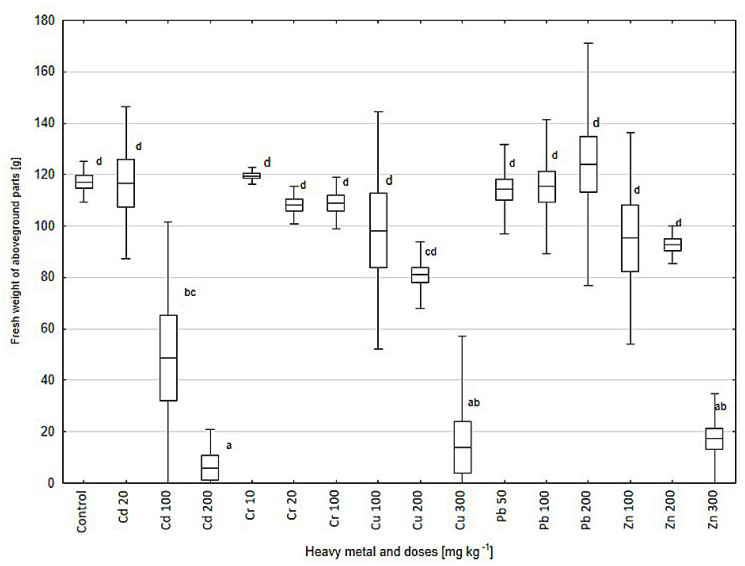

b)

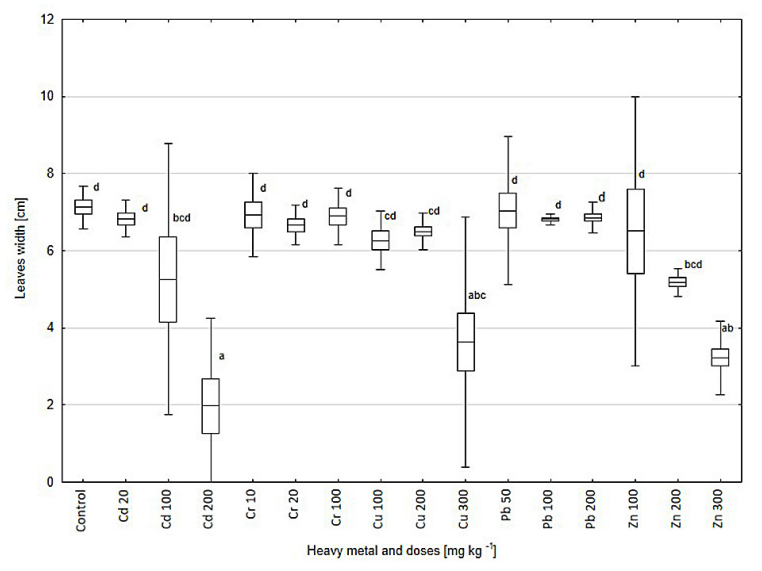

d)

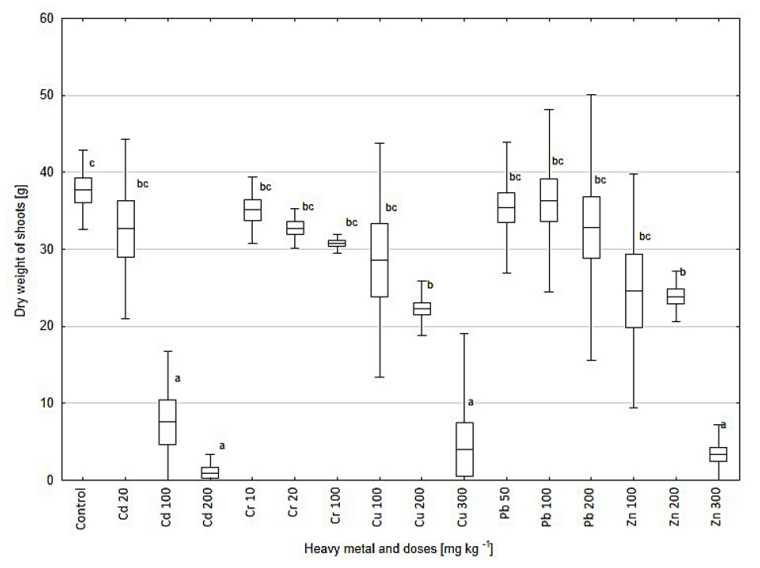

Figure 2. The morphological features of Fallopia japonica in soil cultures with the addition of various metals and in the control variant. The figures show means, standard errors (boxes) and $95 \%$ confidence intervals (whiskers). Different letters in each row show significant differences obtained after Tukey's HSD $(\mathrm{P} \leq 0.05)$

such negative impact on the F. japonica morphology; plants from this variant were similar to the control. $\mathrm{Cu}$ and $\mathrm{Zn}$ also significantly influenced the analysed morphological features of F. japon$i c a$. For example, the fresh weight of the aerial part of plants from pots with $\mathrm{Cu}\left(300 \mathrm{mg} \cdot \mathrm{kg}^{-1}\right)$ was eight and a half times smaller than the control $(\mathrm{F}=20.3511, \mathrm{P}<0.000140)$. The dry weight of the aboveground shoots was less than one ninth of that of the control $(\mathrm{F}=17.7455, \mathrm{P}<0.000249)$. In the case of $\mathrm{Zn}$, soil contamination by $300 \mathrm{mg} \cdot \mathrm{kg}^{-1}$ of this metal resulted in a nearly seven-fold decrease in the fresh mass of the aboveground shoots $(\mathrm{F}=30.5542, \mathrm{P}<0.000012)$ and an elevenfold decrease in their dry matter $(\mathrm{F}=23.2255$, $\mathrm{P}<0.000046)$. The analysis of variance indicated that the morphology of Fallopia japonica from the soils artificially contaminated by $\mathrm{Cr}$ and $\mathrm{Pb}$ did not differ from that of the control plants. Even the highest doses of these metals did not affect the morphological characteristics of the species.

\section{Heavy metal contents in the above- and underground parts of plants}

The analysis of metal concentrations in Fallopia japonica confirmed a high potential of this plant for heavy metal accumulation (Table 2). An increased concentration of metals in soil stimulated their increase in Fallopia japonica. The positive Pearson and Spearman's correlation coefficients (Table 3) indicate a strong relationship between the increasing doses of metals in the soil and their contents in the underground and aboveground part of plants. Among the studied metals, Cd was found in the largest amounts. For example, in the variant where a dose of $100 \mathrm{mg} \mathrm{Cd} \cdot \mathrm{kg}^{-1}$ was applied, the plants (aboveground part) accumulated more than 630 times the amount of cadmium found in the control. In the plant leaves from the soils contaminated with $\mathrm{Zn}$ in doses of $200 \mathrm{mg} \cdot \mathrm{kg}^{-1}$, the average content of 
Table 2. Mean concentrations of heavy metals $\left[\mathrm{mg} \cdot \mathrm{kg}^{-1}\right]$ in organs of Fallopia japonica. Standard errors are given in parentheses. n.d - not determined because the dose was lethal to plants

\begin{tabular}{|c|c|c|c|}
\hline Metals & Doses [mg $\left.\mathrm{kg}^{-1}\right]$ & Under-ground parts & Above-ground parts \\
\hline \multirow{4}{*}{$\mathrm{Cd}$} & Control & 1.3 a $( \pm 1.20)$ & $1.1 \mathrm{a}( \pm 0.43)$ \\
\hline & 20 & 6.9 a $( \pm 1.73)$ & 17.0 a $( \pm 4.40)$ \\
\hline & 100 & $301.8 \mathrm{~b}( \pm 126.12)$ & $700.3 \mathrm{~b}( \pm 339.06)$ \\
\hline & 200 & n.d & n.d \\
\hline \multirow{4}{*}{$\mathrm{Cr}$} & Control & $4.4 a( \pm 6.68)$ & $2.1 \mathrm{a}( \pm 3.49)$ \\
\hline & 10 & $5.5 \mathrm{a}( \pm 1.26)$ & $3.3 \mathrm{a}( \pm 1.06)$ \\
\hline & 20 & $15.05 \mathrm{~b}( \pm 4.01)$ & 3.8 a $( \pm 1.13)$ \\
\hline & 100 & $18.25 \mathrm{~b}( \pm 3.34)$ & $9.3 \mathrm{~b}( \pm 4.17)$ \\
\hline \multirow{4}{*}{$\mathrm{Cu}$} & Control & 7.9 a $( \pm 3.03)$ & $7.2 \mathrm{a}( \pm 2.22)$ \\
\hline & 100 & 19.0 a $( \pm 9.76)$ & 12.0 a $( \pm 5.79)$ \\
\hline & 200 & $37.9 \mathrm{~b}( \pm 5.99)$ & $36.3 \mathrm{~b}( \pm 5.06)$ \\
\hline & 300 & $112.8 \mathrm{c}( \pm 7.52)$ & $48.5 \mathrm{~b}( \pm 12.10)$ \\
\hline \multirow{4}{*}{$\mathrm{Pb}$} & Control & $2.5 \mathrm{a}( \pm 1.71)$ & $1.0 \mathrm{a}( \pm 0.03)$ \\
\hline & 50 & $3.1 \mathrm{a}( \pm 1.75)$ & $2.1 \mathrm{a}( \pm 1.46)$ \\
\hline & 100 & 7.8 a $( \pm 11.99)$ & $4.0 \mathrm{a}( \pm 3.79)$ \\
\hline & 200 & $28.5 \mathrm{~b}( \pm 10.61)$ & $8.6 \mathrm{~b}( \pm 2.06)$ \\
\hline \multirow{4}{*}{$\mathrm{Zn}$} & Control & 25.5 a $( \pm 1.69)$ & 52.4 a $( \pm 8.15)$ \\
\hline & 100 & $115.4 \mathrm{~b}( \pm 28.88)$ & $360.5 \mathrm{ab}( \pm 220.18)$ \\
\hline & 200 & 194.5 c $( \pm 37.99)$ & 563.5 c ( $( \pm 169.68)$ \\
\hline & 300 & n.d & n.d \\
\hline
\end{tabular}

Table 3. Pearson's (p) and Spearman's correlation (Rs) between doses of heavy metals and their contents in underground and aboveground parts of plants

\begin{tabular}{|c|c|c|c|c|c|}
\hline Metals & $\mathrm{Cd}$ & $\mathrm{Cr}$ & $\mathrm{Cu}$ & $\mathrm{Pb}$ & $\mathrm{Zn}$ \\
\hline \multirow{2}{*}{ Under-ground parts } & $\mathrm{r}=0.898$ & $\mathrm{Rs}=0.540$ & $\mathrm{Rs}=0.742$ & $\mathrm{r}=0.884$ & $\mathrm{Rs}=0.827$ \\
& $\mathrm{p}=0.000$ & $\mathrm{p}=0.030$ & $\mathrm{p}=0.001$ & $\mathrm{p}=0.000$ & $\mathrm{p}=0.000$ \\
\hline \multirow{2}{*}{ Above-ground parts } & $\mathrm{r}=0.874$ & $\mathrm{r}=0.760$ & $\mathrm{r}=0.903$ & $\mathrm{r}=0.810$ & $\mathrm{Rs}=0.905$ \\
& $\mathrm{p}=0.000$ & $\mathrm{p}=0.002$ & $\mathrm{p}=0.000$ & $\mathrm{p}=0.000$ & $\mathrm{p}=0.000$ \\
\hline
\end{tabular}

this element was more than 10 times higher than in the control. $\mathrm{Cu}$ and $\mathrm{Pb}$ were mostly accumulated in the underground parts of Fallopia japonica, while the leaves contained smaller amounts of those metals. The plants from the soil polluted with lead $\left(200 \mathrm{mg} \cdot \mathrm{kg}^{-1}\right)$ contained 11 times more of this element than the control plants. In the underground parts of the plants from the pots with the addition of $\mathrm{Cu}$ at $300 \mathrm{mg} \cdot \mathrm{kg}^{-1}, 14$ times more $\mathrm{Cu}$ was found in comparison with the control. Chromium accumulated in both the underground and aboveground parts of Fallopia japonica. The addition of $\mathrm{Cr}$ to the soil at $100 \mathrm{mg} \cdot \mathrm{kg}^{-1}$ resulted in a more than fourfold increase in the concentration of chromium in the underground and aboveground parts of the plants from the contaminated pots compared to the control.

\section{DISCUSSION}

Successful invasive species management depends on a thorough understanding of the biology of the particular organisms (Yasin et al. 2019). The literature on invasive species suggests that the speed of alien weeds in the colonization of new areas is often based on their broad environmental tolerance and ability to adapt to various conditions (Bradley et al. 2010). Moreover, higher tolerance to stressful environments may result in the alien plants being more competitive than natives, thus promoting the process of their invasion (Zhang et al. 2008). Heavy metals are one of the most important environmental pollutants and the toxicity of heavy metals is a problem of ecological and environmental significance (Nagajyoti et al. 2010). Even though some positive changes are 
observed now, the emission of pollutants continues, especially in the heavily industrialised areas (Kicińska 2020). The metal-bearing areas are characterised by low plant biodiversity (Brej and Fabiszewski 2006). It is known that the plants inhabiting extremely stressful environments, such as mining sites, exhibit lower performance under competition compared to nonspecialized plants, because they invest resources in stress resistance at the expense of the performance traits such as biomass. However, the study created by Wani et al. (2019) suggests that, under some circumstances, multiple species may colonize the high-stress habitats from the low-stress habitats without reduced competitive ability. Among the plants that can inhabit the heavy-metal-polluted areas are invasive weed species, e.g., Solidago canadensis (Yang et al. 2007, Zhang et al. 2008), Spartina densiflora (Mateos-Naranjo et al. 2011), Conium maculatum (Gulezian et al. 2012), and taxa of the Fallopia genus (Chmura et al. 2013, Rahmonov et al. 2014, Sołtysiak and Brej 2014). All of these possess strong competitive abilities, but it is less known whether they are resistant to heavy metals or whether the soil contamination by heavy metals impacts the invasion of these exotic weeds. The plants from polluted soils have physiological strategies that allow them to exist under extreme conditions. One such strategy is the resistance to the toxic levels of heavy metals in soils. In order to achieve this, plants can rely on either avoidance or tolerance of heavy metals (Punz and Sieghardt 1993). The first of these concerns the cellular level as well as the level of the whole plant. Avoidance of the stress can refer to the sequestration of toxic metals from the protoplasm and the elimination of heavy metals or avoidance of the uptake of heavy metals from the soil solution. Such a strategy is represented by the invasive Solidago canadensis, which spreads on the soils contaminated by lead (Yang et al. 2007). The metal tolerance strategy of a plant species is a result of genetic, physiological, and ecological evolution. This process unfolded on natural metalliferous areas over a long time. In anthropogenic habitats, the evolution of metal tolerance takes much less time; it depends on the metal levels and on the selection pressure in the environment. The results of this greenhouse experiment provided the evidence that $F$. japonica might have a tolerance to toxic metals. This evidence is summarised below:

1. First, this experiment proved that even high contents of toxic metals $(\mathrm{Cd}, \mathrm{Cr}, \mathrm{Cu}, \mathrm{Zn}$ and
$\mathrm{Pb}$ ) in the soil did not completely eliminate the rhizome's ability to regenerate. However, the presence of some metals $(\mathrm{Cd}, \mathrm{Pb}$ and $\mathrm{Zn})$ delayed the rhizome regeneration at the beginning of the experiment. A similar result was observed by Michalet et al. (2017). They investigated the impact of heavy metals on the rhizome regeneration and growth of the Fallopia genus occurring in the early stages of vegetative propagation, as well as its impact on belowground secondary metabolism. According to Michalet et al. (2017), the delay in the rhizome regeneration of knotweeds induced by the heavy metals is due to plant investment in the production of secondary metabolites than in primary metabolites needed for cell and tissue multiplications. The intensive regeneration of Fallopia species by rhizome fragments has played a very importance role during the vegetative spread all taxa. For example, Vuković et al. (2019) observed that knotweeds were able to establish a stand by rooting from the plant remains cut during maintenance and left by the road. The ability of Fallopia japonica for rapid rhizomes regeneration under different levels of soils contamination makes it a formidable invader, especially on anthropogenic places with higher amount of heavy metals.

2. Second, some metals such as $\mathrm{Cr}$ or $\mathrm{Pb}$ did not have a negative effect on the Fallopia japonica growth. In the soils to which three levels of $\mathrm{Cr}$ and $\mathrm{Pb}$ were added, the shoots of Fallopia japonica grew with similar vigour to the control plants. Only the higher doses of $\mathrm{Cd}$ $\left(100,200 \mathrm{mg} \cdot \mathrm{kg}^{-1}\right), \mathrm{Cu}\left(300 \mathrm{mg} \cdot \mathrm{kg}^{-1}\right)$ and $\mathrm{Zn}$ $\left(300 \mathrm{mg} \cdot \mathrm{kg}^{-1}\right)$ significantly delayed the plants' growth. The highest doses of $\mathrm{Cd}, \mathrm{Cr}, \mathrm{Cu}, \mathrm{Pb}$ and $\mathrm{Zn}$ used in this experiment are acutely toxic to the majority of plant species. The visible symptoms of metal stress in plants include the morphological and structural changes of the aboveground shoots, such as deformation and chlorosis of leaves, leaf necrosis, red and purple leaf discoloration, brown leaf edges, decreases in the leaf number and leaf size, reduced biomass, growth inhibition, and finally death (Benyó et al. 2016). During the greenhouse experiments, no visible symptoms of the toxic metal effects were found in F. japonica from the pots contaminated with any dose of $\mathrm{Cr}$ or $\mathrm{Pb}$. Some toxic symptoms were observed among the plants grown in the soils where $\mathrm{Cd}$ (at 100 or $\left.200 \mathrm{mg} \cdot \mathrm{kg}^{-1}\right) \mathrm{Cu}\left(300 \mathrm{mg} \cdot \mathrm{kg}^{-1}\right)$ or $\mathrm{Zn}$ 
a)

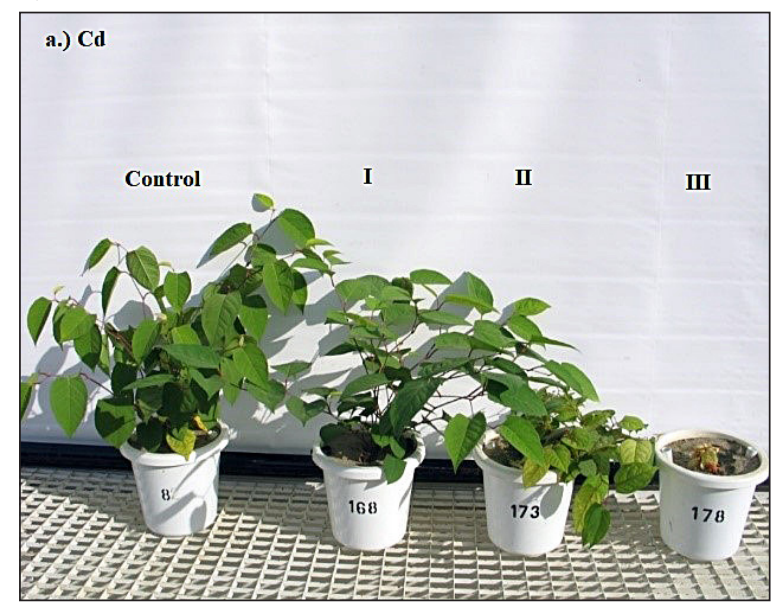

c)

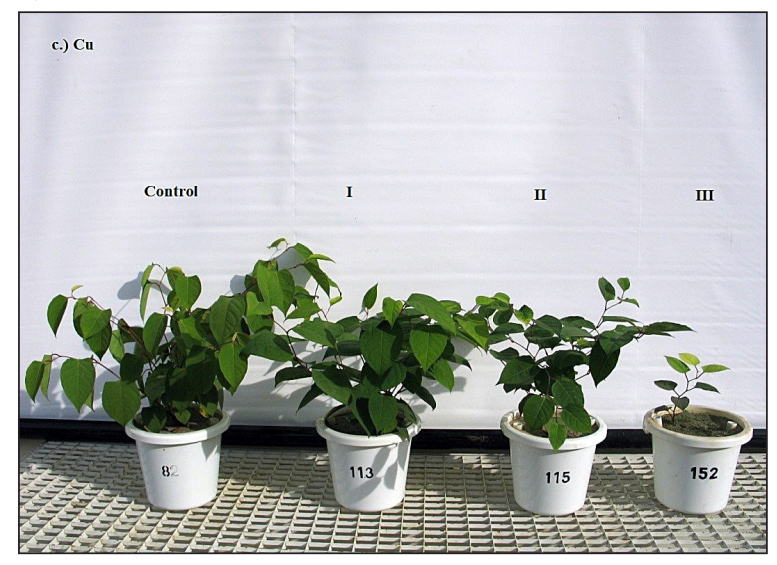

b)

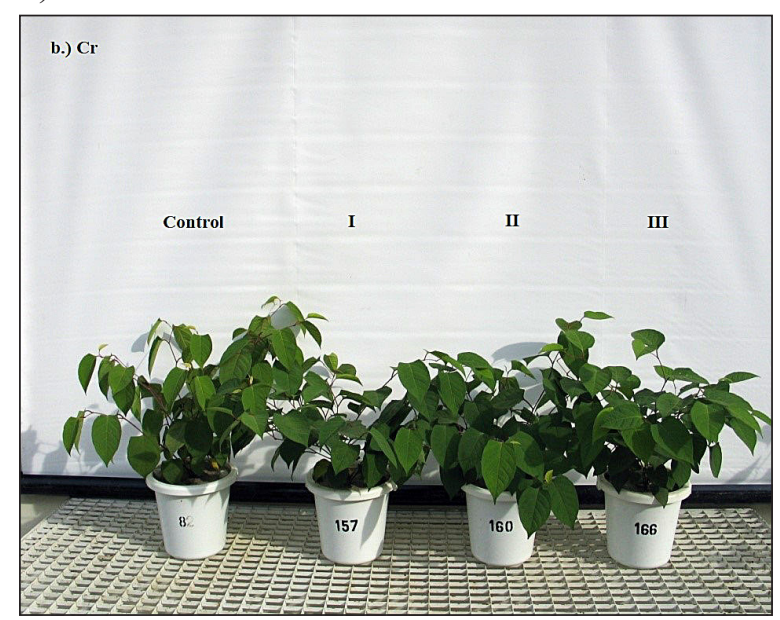

d)

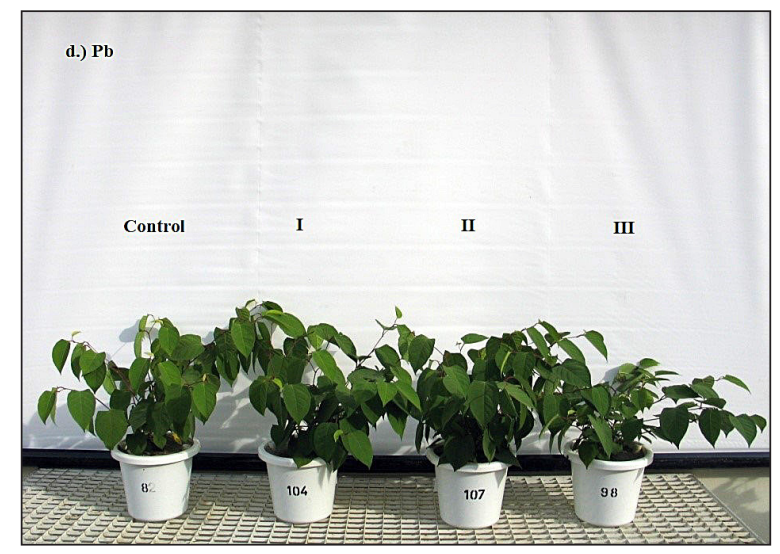

e)

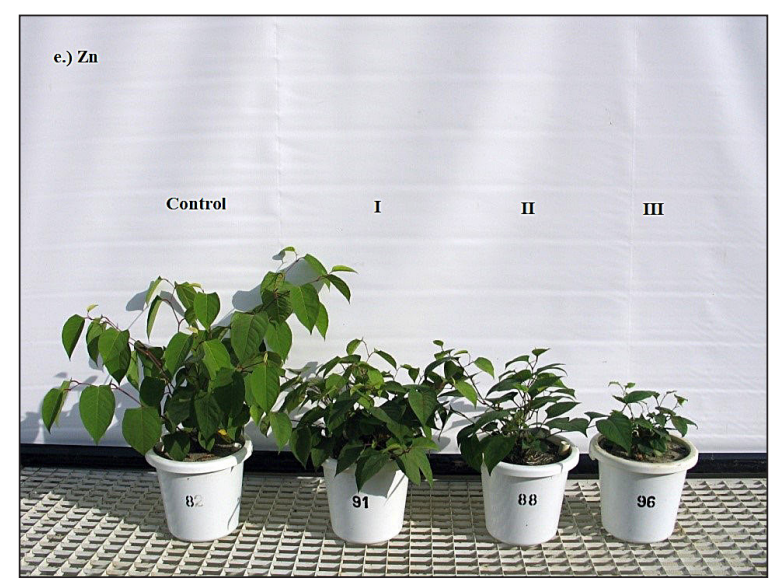

Figure 3. The growth of Fallopia japonica in control variant soil and in soil cultures with the addition of various metals: a) Cd 20 (I), 100 (II), 200 (III) $\mathrm{mg} \cdot \mathrm{kg}^{-1}$; b) Cr 10 (I), 20 (II), 100 (III) $\mathrm{mg} \mathrm{kg}^{-1}$; c) Cu 100 (I), 200 (II), 300 (III) $\mathrm{mg} \cdot \mathrm{kg}^{-1}$; d) Pb 50 (I), 100 (II), 200 (III) $\mathrm{mg} \cdot \mathrm{kg}^{-1}$; e) Zn 100 (I), 200 (II), 300 (III) $\mathrm{mg} \cdot \mathrm{kg}^{-1}$

(300 $\mathrm{mg} \cdot \mathrm{kg}^{-1}$ ) was added (Fig. 3). The morphological changes were especially visible among the plants growing in the soil with the highest amount of $\mathrm{Cd}\left(200 \mathrm{mg} \cdot \mathrm{kg}^{-1}\right)$. Cadmium is a non-essential element that has no metabolic use and is believed to cause damage even at low concentrations. According to Radojevic and Bashkin (2006), 3-8 $\mathrm{mg} \cdot \mathrm{kg}^{-1}$ of $\mathrm{Cd}$ are critical soil concentrations for plants. In the case of $F$. japonica, a higher amount of this 
metal in soils $\left(20 \mathrm{mg} \cdot \mathrm{kg}^{-1}\right)$ did not have a toxic effect for plants (Fig. 3).

3. Third, the analysis of the metal concentrations in plant tissues showed a high potential of $F$. japonica for heavy metal uptake and their intensive accumulation in the aboveground (in the case of $\mathrm{Cd}$ and $\mathrm{Zn}$ ) and underground parts $(\mathrm{Cr}, \mathrm{Cu}$, and $\mathrm{Pb})$. The capacities of $\mathrm{Fal}$ lopia japonica to accumulate heavy metals (such as $\mathrm{Cd}, \mathrm{Pb}, \mathrm{Zn}$ ) under field conditions were proven by Böhmová \& Šoltes (2017) or Rahmonov et al. (2019). Metal accumulation has been recognized as an extreme type of physiological response to heavy metal tolerance (Shaw 1989). Comparing the results of this experiment with the data from the literature, cadmium was removed particularly efficiently in this experiment. In the leaves of plants from the soils polluted by $100 \mathrm{mg}$ $\mathrm{Cd} \cdot \mathrm{kg}^{-1}$, the concentration of this metal exceeded $700 \mathrm{mg} \cdot \mathrm{kg}^{-1}$ (dry weight). This value is much higher than the range of critical concentrations in plant tissues of 5.0 to $30.0 \mathrm{mg}$ $\mathrm{Cd} \cdot \mathrm{kg}^{-1}$ dry weight that has toxic effects in most vascular plants (Radojevic and Bashkin 2006). Especially high levels of cadmium were found in the aerial parts of Brassica juncea and Brassica napus. When exposed to $10 \mathrm{mg} \cdot \mathrm{kg}^{-1} \mathrm{Cd}$, the shoot $\mathrm{Cd}$ concentrations were 238 and $239 \mathrm{mg} \cdot \mathrm{kg}^{-1}$ for Brassica juncea and Brassica napus, respectively, which was approximately 23 times higher than that of plants grown in the control substrate (Alvarez et al. 2009).

The results of the presented greenhouse experiment arouse many questions connected with Fallopia japonica tolerance to heavy metals. At present, the most interesting of them is: how does this characteristic support intensive Fallopia japonica expansion on the metal-contaminated areas? It is suspected that it facilitates the ability of Fallopia japonica to compete with native species and promotes its invasion of such places. These issues must be supported by another years of field research, which are planned to be carried out in the future.

\section{CONCLUSIONS}

On the basis of the results of the presented research, the following conclusions can be drawn:
1. Heavy metals in soil do not eliminate the Fallopia japonica rhizome's ability to regenerate. This conclusion has been especially reached for $\mathrm{Cd}\left(20,100,200 \mathrm{mg} \cdot \mathrm{kg}^{-1}\right) \mathrm{Cr}$ $\left(10,20,100 \mathrm{mg} \cdot \mathrm{kg}^{-1}\right) \mathrm{Cu}\left(100,200 \mathrm{mg} \cdot \mathrm{kg}^{-1}\right)$ and $\mathrm{Zn}\left(100,200 \mathrm{mg} \cdot \mathrm{kg}^{-1}\right)$. In the study reported here, the plants from the pots polluted by these metals had the highest regeneration rates $(100 \%)$.

2. Metals such as $\mathrm{Cr}$ or $\mathrm{Pb}$ do not have a toxic influence on plants' development, which was observed in this experiment. In the soils contaminated with any level of $\mathrm{Cr}$ or $\mathrm{Pb}$, the shoots of this plant grew with similar vigour to the control plants and had the same morphological features as control. High doses of $\mathrm{Cd}$ $\left(100,200 \mathrm{mg} \cdot \mathrm{kg}^{-1}\right), \mathrm{Cu}\left(300 \mathrm{mg} \cdot \mathrm{kg}^{-1}\right)$ and $\mathrm{Zn}$ $\left(300 \mathrm{mg} \cdot \mathrm{kg}^{-1}\right)$ can delay the rapid growth of Fallopia japonica. In the greenhouse experiment, the $\mathrm{Cd}, \mathrm{Cu}$ and $\mathrm{Zn}$ toxicity had also a significant impact on the morphology of Fallopia japonica.

3. An increased concentration of all metals in soil stimulated their increase in plants. This fact proves that Fallopia japonica accumulates heavy metals effectively when grown in contaminated soil. It was particularly observed in the case of Cd. In the aboveground parts of the plants from the pots with the addition of $\mathrm{Cd}$ at $100 \mathrm{mg} \cdot \mathrm{kg}^{-1}, 630$ times more $\mathrm{Cd}$ was found in comparison with the control.

4. The capacities of this invasive weed to regenerate from rhizome fragments, to grow and develop under the stress conditions created by toxic doses of some metals, and to take up metals, all of which were shown in this study, are the evidence that Fallopia japonica has metal tolerance.

\section{Acknowledgements}

I would like to thank Teresa Brej for help with the greenhouse experiment organization and Kateřina Berchová-Bímová for great support of my work and scientific consultation.

\section{REFERENCES}

1. Alvarez S., Berla B.M., Sheffield J., Cahoon R.E., Jez J.M. \& Hicks L.M. 2009. Comprehensive analysis of the Brassica juncea root proteome in response 
to cadmium exposure by complementary proteomic approaches. Proteomics, 9, 2419-2431.

2. Anderson \& Hayley. 2012. Invasive Japanese Knotweed (Fallopia japonica (Houtt.)). Best Management Practices in Ontario. Ontario Invasive Plant Council, Peterborough, ON.[online].https://www.ontarioinvasiveplants.ca/wpcontent/uploads/2016/06/ OIPC_BMP_JapaneseKnotweed.pdf (accessed: 11.05.2020).

3. Bailey J.P. 2003. Japanese Knotweeds s.l. at home and abroad. In: Child, J. H. Brock, G. Brundu, K. Prach, P. Pyšek, P.M. Wade, M. Williamson (eds.), Plant Invasions: Ecological Threats and Management Solutions, Backhuys Publishers, Leiden: 183-196.

4. Bailey J.P., Bimová K., Mandák B. 2008. Asexual spread versus sexual reproduction and evolution in Japanese Knotweed s.l. sets the stage of "Battle of the Clones”. Biological Invasions, 11, 1189-1203.

5. Benyó D., Horváth E., Németh E., Leviczky T., Takács K., Lehotai N., Feigl G., Kolbert Z., Ördög A., Gallé R., Csiszár J., Szabados L. \& Erdei L. 2016. Physiological and molecular responses to heavy metal stresses suggest different detoxification mechanism of Populus deltoides and P. $\times$ canadensis. Journal of Plant Physiology, 201, 62-70.

6. Böhmoá P. \& Šoltes R. 2017. Accumulation of selected element deposition in the organs of Fallopia japonica during ontogeny. Oecologia Montana, 26, 35-46.

7. Bradley B.A., Blumenthal D.M., Wilcove D.S. \& Ziska L.H. 2010. Predicting plant invasions in an era of global change. Trends in Ecology and Evolution, 25, 310-318.

8. Brej T. \& Fabiszewski J. 2006. Plants accumulating heavy metals in the Sudety Mts. Acta Societatis Botanicorum Poloniae, 75, 61-68.

9. CABI. 2000. Invasive Species Compedium, Fallopia japonica (Japaneses Knotweed). [online]. https://www.cabi.org/isc/datasheet/23875 (accessed: 11.05.2020).

10. Chmura D., Nejfeld P., Borowska M., Woźniak G., Nowak T. \& Tokarska-Guzik B. 2013. The importance of land use type in Fallopia (Reynoutria) japonica invasion in the suburban environment. Polish Journal of Ecology, 61, 379-384.

11. Ellstrand N.C., Schierenbeck K.A. 2000. Hybridization as a stimulus for the evolution of invasiveness in plants? Proc. Natl. Acad. Sci. USA, 97 (13), 7043-7050.

12. Fennell M., Wade M. \& Bacon K. L. 2018. Japanese knotweed (Fallopia japonica): an analysis of capacity to cause structural damage (compared to other plants) and typical rhizome extension. [online]. Website https://peerj.com/articles/5246/ (17.08.2019).
13. Gulezian P.Z., Ison J.L. \& Granberg K.J. 2012. Establishment of an invasive plant species (Conium maculatum) in contaminated roadside soil in Cook County, Illinois. The American Midland Naturalist, 168, 375-395.

14. Kicińska A. 2020. Lead and Zinc in Soils Around a Zinc-Works - Presence, Mobility and Environmental Risk. Journal of Ecological Engineering, 21(4), 185-198.

15. Mandák B., Bímová K., Pyšek P., Štěpánek J. \& Plačková I. 2005. Isoenzyme diversity in Reynoutria (Polygonaceae) taxa: escape from sterility by hybridization. Plant Systematics and Evolution, 253, 219-230.

16. Mateos-Naranjo E., Andrades-Moreno L. \& Redondo-Gomez S. 2011. Comparison of germination, growth, photosynthetic responses and metal uptake between three populations of Spartina densiflora under different soil pollution conditions. Ecotoxicology and Environmental Safety, 74, 2040-2049.

17. Michalet S., Rouifed S., Pellassa-Simon T., FusadeBoyer M., Meiffren G., Nazaret S., Piola F. 2017. Tolerance of Japanese knotweed s.l. to soilartificial polymetallic pollution: early metabolic responses and performance during vegetative multiplication. Environ. Sci. Pollut. Res. Int., 24 (26), 20897-20907.

18. Nagajyoti P.C., Lee K.D. \& Sreekanth T.V.M. 2010. Heavy metals, occurrence and toxicity for plants: a review. Environmental Chemistry Letters, 8, 199-216.

19. Nentwig W., Bacher S., Kumschick S., Pyšek P. \& Vilà M. 2018. More than"100 worst"alien speciesin Europe. Biological Invasions, 20, 1611-1621, DOI: 10.1007/s10530-017-1651-6.

20. Vilá M., Corbin J.D., Dukes J.S., Pino J. \& Stanley S.D. 2007. Linking plant invasion to global environmental change. In: Canadell J.G, Pataki D.E, Pitelka F.L. (editors). Terrestrial Ecosystems in a Changing World.

21. Vuković N., Šegota V., Alegro A., Koletić N., Rimac A. and Dekanić S. 2019. "Flying under the radar" how misleading distributional data led to wrong appreciation of knotweeds invasion (Reynoutria spp.) in Croatia. Bio. Invasions Records, 8 (1), 175-189.

22. Pauková Ž. 2019. Occurrence and Spread after 18 Years of Invasion by Fallopia $\times$ bohemica (Slovakia). Journal of Ecological Engineering, 20 (3), 85-90.

23. Punz W.F. \& Sieghardt H. 1993. The response of roots of herbaceous plant species to heavy metals. Environmental Botany, 33, 85-98.

24. Radojevic M. and Bashkin V.N. 2006. Practical Environmental Analysis. 2nd ed. United Kingdom, RSC Publishing.

25. Rahmonov O., Czylok A., Orczewska A., Majgier L. \& Parusel T. 2014. Chemical composition of the 
leaves of Reynoutria japonica Houtt. and soil features in polluted areas. Central Europea Journal of Biology, 9, 320-330.

26. Rahmonov O., Banaszek B., Pukowiec-Kurda K. 2019. Relationships Between Heavy Metal Concentrations in Japanese Knotweed (Reynoutria Japonica Houtt.) Tissues and Soil in Urban Parks in Southern Poland. IOP Conf. Series: Earth and Environmental Science 221012145 IOP. doi:10.1088/1755-1315 /221/1/012145.

27. Sharma G.P., Singh J.S. \& Raghubanshi A.S. 2005. Plant invasion: emerging trends and future implications. Current Science, 88, 726-734.

28. Shaw A. J. 1989. Heavy Metal Tolerance in Plants: Evolutionary Aspects. CRP Press INC, Floryda, The United States, CRP Press INC.

29. Sołtysiak J., Berchová-Bímová K., Vach M., Brej T. 2011. Heavy metals content in the Fallopia genus in central European Cities - study from Wroclaw and Prague. Acta Botanica Silesiaca, 7, 209-218.

30. Sołtysiak J. and Brej T. 2014. Invasion of Fallopia genus plants in urban environment on the example of Wrocław city. Polish Journal of Environmental Studies, 23, 449-458.

31. Sołtysiak J. and Brej T. 2019. Effect of soil artificially polluted with lead on an invasive Fallopia $\times$ bohemica: a case study from Central Europe. Polish Journal of Environmental Studies, 28, 1-9.
32. Tokarska-Guzik B., Dajdok Z., Zając M., Zając A., Urbisz A., Danielewicz W., Hołdyński C., 2012. Rośliny obcego pochodzenia w Polsce ze szczególnym uwzględnieniem gatunków inwazyjnych. Generalna Dyrekcja Ochrony Środowiska, Warszawa [in Polish].

33. Tokarska-Guzik B., Fojcik B., Bzdęga K., Urbisz A., Nowak T., Pasierbiński A., Dajdok Z. 2017. Inwazyjne gatunki z rodzaju Reynouria spp. w Poslce - biologia, ekologia i metody zwalczania. Wydawnictwo Uniwersytetu Śląskiego w Katowicach [in Polish].

34. Wani S.H., Fazlioglu F., Bonseri S .P. 2019. Competitiveness of generalist plant populations at a mine site. Turkish Journal of Botany, 43 (2), 218-231.

35. Zhang Qian, Yang Ruyi, Tang Jianjun \& Chen Xin. 2008. Competitive interaction between the invasive Solidago canadensis and native Kummerowia striata in lead contaminated soil. Botanical Studiem, 49, 385-391.

36. Yang Ru-Yi, Tang Jian-Jun, Yang Yi-Song \& Chen Xin. 2007. Invasive and non-invasive plants differ in response to soil heavy metal lead contamination. Botanical Studies, 48, 453-458.

37. Yasin M., Rosenqvist E., Jensen S.M. \& Andreasen C. 2019. The importance of reduced light intensity on the growth and development of six weed species. Weed Research, 59, 130-144. 